\title{
Introduction. Islamicate Lucknow Today: Historical Legacy and Urban Aspirations
}

Raphael Susewind and Christopher B. Taylor

\section{OpenEdition}

\section{Journals}

\section{Electronic version}

URL: http://journals.openedition.org/samaj/3911

DOI: 10.4000/samaj.3911

ISSN: 1960-6060

\section{Publisher}

Association pour la recherche sur l'Asie du Sud (ARAS)

\section{Electronic reference}

Raphael Susewind and Christopher B. Taylor, « Introduction. Islamicate Lucknow Today: Historical Legacy and Urban Aspirations », South Asia Multidisciplinary Academic Journal [Online], 11 | 2015, Online since 15 July 2015, connection on 19 April 2019. URL : http://journals.openedition.org/samaj/3911 ; DOI : 10.4000/samaj.3911

This text was automatically generated on 19 April 2019

\section{$(1) \Theta \Theta$}

This work is licensed under a Creative Commons Attribution-NonCommercial-NoDerivatives 4.0 International License. 


\title{
Introduction. Islamicate Lucknow Today: Historical Legacy and Urban Aspirations
}

\author{
Raphael Susewind and Christopher B. Taylor
}

\begin{abstract}
Acknowledgements: We would like to thank Sandria Freitag, Nandini Gooptu, and our audiences at the Association for Asian Studies' annual meeting in Philadelphia (2014) and at the European Conference for South Asian Studies in Zurich (2014) for their critical contributions to the two panels that led to this special issue. We also thank the four anonymous reviewers for their comments on this introduction. We acknowledge the assistance of Editage in language editing.
\end{abstract}


1 The Lucknow Clocktower (ghanta ghar) rises 200 feet into the air over the old neighbourhood of Husainabad. Its orderly, measured timekeeping is juxtaposed against the chaos of traffic passing through the nearby Rumi Gate (roomi darwaza), the historical entrance to Lucknow City from the direction of Istanbul, known to the Persianate world as 'Room.' Erected in 1881

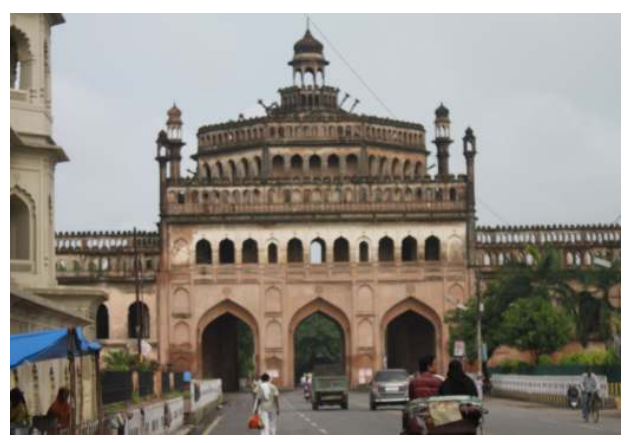
in the capital of the areas known to the British as the United Provinces of Awadh and Agra, the Clocktower is built testimony to changing times. In the wake of the British victory over the 1857 rebellion that was sparked within garrisons of Indian troops stationed in Lucknow and elsewhere, the city was thoroughly reimagined by its new rulers and its old residents alike. As imperial control was reinstated and deepened, Lucknow became more intensely connected with other parts of British India, both politically and through better infrastructure. Key to this process was the city's connection to the railway network, which required exact timekeeping and, hence, a clocktower (Llewellyn-Jones 1985: 181).

2 But it was over a century ago that this all happened. For decades, the Lucknow Clocktower has been stopped, its hands frozen. No one has deigned to repair it: not the successors to the royal rulers of Lucknow who originally erected it nor the current elected government of Uttar Pradesh, India's largest state, of which Lucknow became capital after independence. The monument is a product of colonial politics and a nuanced past (Llewellyn-Jones 1985). Its presence stands as a metaphor for the agency (or lack thereof) that citizens of Lucknow feel with regard to their past-it is representative of history as a controlling and controllable force in the life of the present. Though we recognise that neither were intended to bear a symbolic load, we take the Clocktower and a quip from one of our informants-that Lucknow has 'too much history'-as points of departure for examining Lucknow residents' cultural memories of both their own histories and of 'History,' broadly conceived. In contrast to Hayden White's (2014 [1966]) famous essay 'The Burden of History', however, we do not critique the discipline of history for having become mired in antiquated analytics of the societies under study, precluding interdisciplinary dialogue with scholars of contemporary social life. Rather, we rely on contemporary Lucknow residents' own views of 'history' as a touchstone for interdisciplinarity and broader scholarly collaboration among South Asianists.

3 We have privileged emic views; thus, the various papers in this volume naturally conceive of the contemporary role of history in different ways. First, like the unrepaired Clocktower, history in Lucknow can appear visibly present while going unnoticed: unseen by the residents of Lucknow, who continue to lead their everyday lives and to move about their town and the world, the past continues to influence current events. Endeavour as they may to leave history behind, residents for instance explicitly recognise the everyday presence of history whenever they refer to the old city as 'old' (qadimi; purani).

4 Secondly, history's presence can also overwhelm, casting a shadow at least as long as that of the Clocktower. In the eyes of many residents and observers that we spoke with, contemporary Lucknow appears frozen in time, overly burdened by its past. In particular, young people experience the oft-mentioned nostalgia for a bygone civilised culture ( 
tehzib; see Jones, this volume) as an obstacle; they desire to escape traditional institutions and identities and not be reminded of them. As one of our informants, a young and ambitious man in his twenties, put it when asked why he decided to leave the city where he was born: 'there is just too much history here.'

Lastly, Lucknow residents today are capable of repurposing history as a tool to reclaim agency. In 2011, a team of citizens arranged for private funds to get the Clocktower ticking again, attempting to breathe life into a bygone monument, to transform heritage into a marketable resource, and hence, to illustrate the agency Lucknowis have in making the past present. This agency lies at the core of the articles assembled here. This special issue highlights how Lucknow's history is being (re)presented in various contestations, revisions, and alternate visions in the hope that recasting 'what once was' can influence 'what is to be.'

6 The remainder of this introduction situates this special issue within the growing scholarly concern with second-tier Indian cities, reviews earlier scholarship on Lucknow and its historical development, sketches trends in urban expansion and maps out several of Lucknow's demographic features, and finally, introduces the articles themselves. We place particular emphasis on nawabi Lucknow's oft-cited history of Islamicate culture, referring 'not directly to the religion, Islam, itself, but to the social and cultural complex historically associated with Islam and the Muslims, both among Muslims themselves and even when found among non-Muslims' (Hodgson 1974: 57-59). This is not only reflective of popular imaginaries of Lucknow but also of the fact that the old city-where the burden of history is perhaps most acutely felt-is still demographically dominated by Muslims, who comprise India's largest religious minority group and who have recently become subject to increasing scholarly analysis of their socioeconomic 'backwardness' and urban segregation (Sachar et al. 2006, Misra et al. 2007, Basant \& Shariff 2010, Gayer \& Jaffrelot 2012). The subsequent articles thus focus on how the Muslims of Lucknow's old city negotiate a remembered cosmopolitanism and a present burdened by structural violence and ghettoisation while tracing the strong influences of the city's non-Muslim history and presence.

\section{The City in India-Urban Locality as a Scholarly Object}

7 Recalling the Gandhian ideal of India's spirit, the village was the primary analytical trope in early studies on Indian society; it was juxtaposed with colonial urban forms and modernisation, which were represented as inauthentic and foreign (Brosius 2013: 62-63, cf. Gandhi 1966 [1921], Khilnani 1997: 109, Nandy 2006: 13-25). Yet, as Ashis Nandy writes, 'India may live in its villages, but it also has one of the world's oldest continuous traditions of urban living' (2002:126). What are the implications of a more urban perspective for the academic study of India? Is there a model 'Indian city,' and if so, what is it? Can scholars gain insight into the sociology of India by positing a notion of 'the Indian city? What contributions and interventions are possible from the study of Lucknow-overwhelmingly represented in historical accounts-as a contemporary instance of the Indian city?

8 Until recently, studies on Indian cities were largely limited to quantitative research conducted by policymakers and urban planners on urbanisation (e.g. Ramachandran 1989, Sharma \& Sita 2001). 'Most ethnographers ignored the centrality of urban places in the lives of ordinary Indians across the subcontinent' (de Neve \& Donner 2006:5). When 
anthropologists have focused their research on cities, their conclusions have often been related to the transformation of 'traditional' life and related changes in village culture (Bose 1968, Siddique 1982, Rao 1986) or to specific caste groups' efforts to maintain social continuity in the urban milieu (Singer \& Cohen 1968, Lynch 1968). In this sense, rather than take 'the city' as a proper object of study, studies on Indian cities have taken 'the city' as a negative catalyst for cultural groups under observation. Urban neighbourhoods portrayed in earlier ethnographies-expressed in terms such as mohalla, para, basti, or nagar-themselves resembled classic villages: bounded, part of the background, and static (see Appadurai 1995 for a broader critique). Ironically, this has not at all been the case in the discipline of history: urbanisation and urban social relations have figured prominently in historians' work on South Asia, especially with respect to the 19th century (e.g. Bayly 1975, Dobbin 1972, Ballhatchet \& Harrison 1980, Frykenberg 1986; Subrahmanyan 1990; Gooptu 2001).

Since the 1990s, however, scholarship on contemporary urban India has finally begun to chime in with what Gyan Prakash (2002) has called 'the urban turn' in South Asian studies; similarly, Shatkin (2013: 1) spoke of India's 'remarkable urban moment.' This turn began with a heavy focus on the metropolises of the subcontinent colloquially known, by their bureaucratic designation, as 'Tier One cities': Delhi, Bombay, Bangalore, Chennai, Hyderabad, and Calcutta. Tier One cities have often been considered sites where (colonial) modernity was introduced to India (Haynes \& Rao 2013) rather than as true 'localities' (Appadurai 1995) that should be studied for their distinctive emplacement of identity and sociality. In this way, India's Tier One metropolises have been studied more as hinges between tradition and the modern era or as conduits for global flows rather than as sites with precise geographical and historical contours.

In their seminal edited volume, de Neve and Donner (2006:3) emphasised that 'smaller towns are equally important sites for the study of globalisation and its processes' as are India's metropolises. As we elaborate in the next section, Lucknow has been a centre of transnational trade, culture, and learning since the 18th century. It remains an important site of globalisation in India, continually inhabited by a well-educated, worldly elite, but increasingly a labour market where low-cost labour is in excess. The study of Tier Two cities in India has increased; against localised urban backdrops, national themes have appeared in sharper relief. Data from urban India has motivated a recent movement in anthropology to respatialise the state according to the 'here' of local institutions and everyday politics rather than as a bounded state vertically elevated above Indians' ordinary lives (Ferguson \& Gupta 2002, Gupta 2012). Moreover, recent work has portrayed the state in India as a disciplining, yet self-contradictory, entity that is 'palpable' even when ordinary urban Indians visit health clinics (Gupta 2012) and cinemas (Schulz n.d.). The politics of national parties like the CPI(M), for example, are subject to the influence of geographical constraints and the local concerns of neighbourhoods (Chakrabarti 2006). Social institutions like education (Jeffrey et al.2008, Taylor, this volume), caste (Mines 2006), and gender (Donner 2006, Hong Tschalär, this volume) can refashion the very layout of urban neighbourhoods in small cities in ways that would not occur in the context of metropolitan real estate. Reframing age-old analyses of hierarchy in Indian society (Dumont 1980), ethnographies of India's small cities have revealed new modes by which caste-based status is distinguished in the anonymity of increasingly urban environs through social exclusion (Froystad 2006; Susewind, this volume), consumption (Dickey 2013, Liechty 2003), and personal names (Lee, this volume). 
11 Accounting for the above analyses, current scholarship on Indian cities has thus aimed to explain how local institutions remake urban space and emplace intangibles of Indian culture and discourse. Rural and urban India alike are known for their various kinds of diversity-of religion, gender, ethnicity, language, caste, class, and more-and yet every Indian city is also characterised by an astonishing multiplicity of intersections, parallel lives, frequent collisions, and trafficking of all sorts, marking everyday sociality as much as vehicular life does. Despite the flood of economic and demographic data that ceaselessly flows from government and scholarly channels, no one statistical snapshot can capture the complexity of an Indian city (though the next section is one attempt at this). The tin roofs of urban settlements appear and shift with a rapidity that frustrates the attempts of both urban planners and social scientists. City residents, visitors, and ethnographers alike remark that cities in India are bewildering places, 'barely comprehended' even by those living there for decades (Gandhi \& Hoek 2012:4). The Indian city is therefore quite amenable to ethnography, with its methodological sensitivity to subjectivities, inclusion of perspectival orientations, ambiguity, and ambivalence.

12 The city, on the other hand, is also home to bewildering possibilities, a second defining characteristic of Indian urban sociality in contrast to village life. Perpetual instability gives rise to creative energy as diverse communities jostle contentiously in adjacent spaces. In Lucknow, for example, we have observed how public space has been repurposed in myriad ways, as madrasa lawns host inter-city soccer matches, rickshaws conceal lovers' trysts, old alleyways double as industrial workshops, and municipal wastelands become sacred prayer grounds. This 'spatial potentiality,' or the 'use and abuse of ordinary space' (Gandhi \& Hoek 2012: 6-7), intensifies contestations. No turf is safe from intrusion. Traditional group boundaries not only must be policed but also come to be defined in opposition to new adjacent Others (Barth 1969). Urban space is particularly conducive to new openings for reworking gender roles and to facilitating opportunities for women (Hong Tschalär, this volume). Heterogeneity is on display, with differences layered on differences, and invisible class conflict may emerge in performative ritual contests, such as in the context of Shi'a-Sunni strife in the old city of Lucknow (Susewind, this volume).

13 Yet even as they intensify contestation, cities also intensify collaboration. The heightened politics of urban spaces lead to more-and stranger-bedfellows. Diversity and coexistence with the Other become themselves markers of an urbane identity. The cosmopolitanism of India's cities affiliates citizens with the global as much as with the homogenous notions of the 'nation' (Lahiri 2010). Global linkages as well elicit limitless aspirations, while also tying Indians to new fetters of consumerism (Fernandes 2006). Cities are analytically ripe for the study of upward social mobility in India, as well as its opposite: impoverishment.

While groupism is at times superseded in urban India, kinship and group segregation remain social forms of organisation. The politics of violence have continued to remake urban spaces into the 21st century: Indian Muslims have engaged in self-segregation in search of safety, which has paradoxically also increased their socioeconomic vulnerability (Gayer \& Jaffrelot 2012). Bodily performing a group identity has taken on a heightened importance in the anonymity of city streets; markers of class, caste, and religion can cause people to be allowed entry or denied passage in urban neighbourhoods policed through 'apprehending' difference (Gandhi \& Hoek 2012, Dickey 2013). Identities are 
mapped onto the city landscape: as Ghassem-Fachandi (2012) reminds us of Ahmedabad after the riots, bridges, police posts, temples, and shrines became navigational clues regarding communal safety and danger.

Given their potentialities, Indian cities have given rise to new, broader forms of representation than those seen in rural areas. People of lower castes and other minorities are increasingly challenging old hegemonies, democratising elite modes of sovereignty as well as respectability. Indian cities are known for their 'mash-up of visual styles often considered by the city's betters to be gauche, kitsch, or derivative' (Gandhi \& Hoek 2012: 7-8). Yet this 'democratic revolution' in the aesthetics of modernity is not merely imitative, as new modes of respectability and ways of being modern arise through identification with the forces of economic and political progress. This is particularly true of Lucknow. Of course, Mayawati's reign was exemplary in this regard as it facilitated a new Dalit aristocracy. But Lucknow has been home to a blend of modernities, varieties of respectability, and preferences for the old as well as the new ever since the time of the Persianate nawabs, who were famous for their patronage of both European style and Shi'a traditionalism.

Our focus on neighbourhoods as meaningful places runs counter to much of the literature on globalisation, in which the local is characteristically opposed to the global, with the latter representing agency, modernity, and change. Lucknow as a city with 'too much history' seems a perfect candidate for emplacing the local as contiguous with a timeless past. Yet seemingly new (and even neoliberal) developments in India are often characteristic more of the subcontinent's past history than they are representative of India's globalising present, as shown in Patrick Neveling's (2014) long history of exclusion in 'special economic zones' and Nandini Gooptu's (2013) edited collection on the traditional roots of neoliberal enterprise cultures. Similarly, the articles in this volume sharply contrast with the view that Lucknow localities are 'of the past' while outside forces represent 'modernisation' or 'the future.' Instead, we offer nuanced pictures of Lucknow's residents- Dalit activists, Shi'a preachers, madrasa students, and real estate moguls-whose activities contain kernels of the 21st century's hybridisations and creolisations, despite many attempts to represent themselves as guardians of tradition.

\section{History and Historiography in Lucknow}

17 Legends attribute Lucknow's origins to Lakshman, the brother of the Hindu god Ram; the eponymous Lakshman Tila area of the old city retains the stamp of this history (Hjortshoj 1979: 17) and of Lakhna, the builder of Macchi Bhawan palace (Sharar 2001 [1974]: 37). In contrast to its legendary associations with Hindu rulers, Lucknow is also known as the home of the 'Muslim' court of the nawabs, 'leading to the perception that the city was the court' (Wilkinson-Weber 1999: 14). In fact, Lucknow did not exist as an urban centre until the arrival of Asaf al-Dawlah in 1775, the nawab who moved the seat of the Awadh government there from Faizabad in 1775 (Hjortshoj 1979: 20). European visitors to Lucknow from the 18th century onwards marvelled at its palaces and bustling commercial life but consistently remarked on the squalor and poverty among its underclass (Llewellyn-Jones 1980: 11-12, Talwar-Oldenburg 1984: 11).

Lucknow is remembered in the popular imagination of its inhabitants as a city rife with history, for good reason. First of all, historical Lucknow truly was a world-class city; those who know its past take pride in Lucknow's moments on the global stage. Lucknow of the 
18th and 19th centuries surpassed Delhi as the most fabulous court city in the subcontinent' (Talwar-Oldenburg 1984: 213). In 1856, its population was reckoned to be 1 million and it remained the 'largest city in India except for the three Presidency towns of Calcutta, Madras, and Bombay as late as 1870' (Trivedi 2010: 13). Lucknow was thus larger than any city in America at the time and almost half the size of London, then the largest city in the world. During this age of empires, Lucknow retained territorial and cultural integrity long after 1700, when its patrons, the Mughal court in Delhi, began to decline. Since its founding as the nawab's capital in 1775, Lucknow was a cosmopolitan blend of world civilisations under the urbane rule of the nawabs, still visible in its art and architecture today: Edwardian verandas grace local houses that also have square Hindutemple door frames, a Japanese pagoda covers a manor's outbuilding, and Persian motifs are etched in numerous mosques of the era. The nawabs hired French as teachers, tailors, and merchants while protecting local industries and the economy with a tariff wall in 1773 against the East India Company's expansions (Trivedi 2010: 13-15). Lucknow's literati contributed whole genres to Hindustani and Urdu, shaping the development of north Indian literatures (Petievich 1992, Naim \& Petievich 1997, Bard 2002, Trivedi 2010). Lucknow's courtly elite included a well-organised Shi'i class of transnational financiers whose religious donations grew Iraq's shrine cities into two of the most sociopolitically influential hubs of the Middle East (Cole 1988).

Second, though other religiocultural influences were strong (Talwar-Oldenburg 1985: 5, 80-82, 244-246), Lucknow's past is very much an Islamicate past. As Francis Robinson (1977: 300) wrote, 'Though the city was part of India, it was also part of a supra-national Islamic world in which men and ideas circulated with great freedom.' Quoting Abdul Halim Sharar, the 20th-century chronicler of Lucknow's past (Sharar 2001 [1974]), he added, 'Persians here showed themselves in their true light. Thus Persian culture, which had been nurtured in the stately and majestic laps of the Sassanid and Abbasid dynasties, permeated the society of Lucknow.' The 'ulama of Firangi Mahal in Lucknow taught the Greco-Roman humanistic subjects of grammar, logic, philosophy, and rhetoric (a mainstay of Perso-Arab Islamic education) with a greater emphasis than in madrasas today. Both Sunni and Shi'a clergy studied at Firangi Mahal and went on to advise the nawab court as jurists and counsellors (Robinson 2001). The collection of texts that came to be taught as the madrasa 'curriculum' all over Muslim India was standardised by Maulana Nizam al-din Muhammad (d.1748), the leading scholar of Firangi Mahal (Robinson 2001, cf. Zaman 2003:65-68). With the leadership of Islamic scholars in Lucknow, Delhi, and Hyderabad, India attained hitherto unknown prominence in the Islamic world, leading Albert Hourani to label the 18th century the 'Indian Century' of Islam's history (Metcalf 1982: 9).

Twelver Shi'ism is often represented as a global, transnational religious tradition cantered in Najaf and Karbala, Iraq and Qom, Iran. However, Lucknow's Shi'i elite came to define a distinctly 'Indian' Shi'ism. Patronised by the nawabs, Lucknow Shi'a placed a far greater emphasis on certain ritual formulations than on the Middle Eastern roots of their ancestors. The 'Great' (bada) Imambarah of Lucknow, built in 1784 to house the Muharram majlis rituals, represented not only the nawabs' utilisation of Shi'ism as a legitimising ideology (Cole 1988) but also represented a clear departure from similar Iranian religious structures. In global Shi'ism, 'there were no clear precedents for the Great Imambarah. Thus, it is a highly original concept' (Keshani 2003: 249). Associated rituals, such as mourning meetings (majlis) and elegies (marsiya), were developed in 
Lucknow along distinctive lines (Naim 1983, Bard 2002). Moreover, Lucknow's Shi'i revival of the late 18th century led to Sunni-Shi'a sectarian divides and to a notion of doctrinal groups as entirely separate 'communities' with their own public identities (Freitag 1989: 142, Jones 2011:27-28). 'The divisive nature of some Shi'i practices, especially cursing the caliphs honoured by Sunnis and forbidding Hindu celebrations during Muharram, encouraged the growth of an incipient communalism' (Cole 1988: 93). The result was the emergence of a distinctly 'Hindustani' Shi'ism that characterised nawabi Lucknow more than did either Indo-Persian or British colonial influence (Jones 2011: 20).

Third, Lucknow was the setting for key colonial encounters on the subcontinent, in particular, the 1857 Mutiny (discussed below); in historical portrayals, this Lucknow lives on today in the popular imaginary. In other, less militaristic, colonial encounters, the city's history writ small has served as a stand-in for Indian developments writ large. Seema Alavi's (2008) narrative of the encounter between British and Indian Muslim medical traditions based on the Greek texts of Avicenna was based in Lucknow, as was Joshi's depiction of colonial north India's middle-class modernities (Joshi 2001). Portrayals of the art and architecture of Lucknow's past abound as illustrative of the subcontinent's colonial hybrid aesthetics (Llewellyn-Jones 1985, Markel 2010). Given these strongly looming forces of history, colonial modernity itself only arrived as a 'fractured modernity' in Lucknow (Joshi 2001).

The contemporary city meanwhile became the political crucible of independent India. Six out of thirteen Prime Ministers of India have hailed from what was formerly Awadh. Lucknow and its surroundings are key constituencies for taking the electoral pulse of the Hindi heartland of north India. Lucknow was home to the rapidly alternating governments of the Samajwadi Party (SP) led by Mulayam Singh Yadav and the Bahujan Samaj Party (BSP) led by Mayawati, India's first Dalit Chief Minister. Both are icons of the 'silent revolution' (Jaffrelot 2003) of lower castes that transformed Indian politics in the 1980s and ' 90 s (cf. Omvedt 1994). Mayawati, moreover, has shaped the urban landscape of the city with statues, memorials, and parks in homage to Dalit leaders-an architectural political statement that has reverberated all over India.

Chronicles of Lucknow have played a part in shaping genres of English historiography and the discipline of history itself. The Rebellion of 1856-57 and historical accounts of the bloody resistance in Lucknow loomed large in the British imagination, leading historians to theorise the role of popular literature in defining images of colonialism in English society in the wake of increases in mass literacy (Chakravarty 2005). For nationalist Indian historiographers of the 1950 s and '60s, the particularly 'nationalist' or 'popular' character of 1857-era Awadh was a heuristic representation of the spirit of the nascent Indian nation (Sen 1977, Chaudhuri 1965, Datta 1967, cf. Majumdar 1957). The Mutiny also figured in Marx and Engels' (1975) application of historical material dialectics to critique imperialist exploitation. Ranajit Guha's path-breaking study, which launched the subaltern studies, relied heavily on revising the typical colonial depiction of the 1857 Rebellion (Guha 1983, Bhadra 1985). Sandria Freitag's (1989) book was a landmark in social history; in describing the public culture of Lucknow's built environment, collective festival activities, religious events, crowds, rites, sacred spaces and times, it added to the historian's methodological toolkit (cf. Habermas 1991, Haynes 1991, Burke 1997, Hunt 1989). Freitag's work on Lucknow was also an early sign of a developing productive exchange of analytic concepts, such as concepts related to communities and symbolisms 
(Freitag 1989: 146, Turner 1969, Geertz 1973) and visual culture (Freitag 2014, Mitchell 2014), between historians and anthropologists.

\section{Urban Expansion and Demographic Makeup}

The key points in the historical imagination of Lucknow that have been addressed thus have strong spatial connotations. Lucknow's bifurcation into 'old' and 'new' cities is suggestive of its urban development as a model colonial city (King 1976; for critiques, see Haynes and Rao 2013; Chandavarkar 2009): across the banks of the Gomti River, New Lucknow faces off with old Lucknow and life on either side proceeds according to different notions of space, order, and morality. The distinction between the old and new cities remains highly salient for residents. Migrants are said to settle on the city fringes; the old city is seen by many as the pinnacle of tehzib and a place where civility is guarded (as well as the core of Lucknow's Muslim ethos); and for our interlocutors, crossing of the river is fraught with meaning and ambivalence. To continue our introduction of Lucknow from a different angle, we turn to a series of maps to see how this rich historical imagination relates to physical space. These maps locate key spatial features, areas, and institutions; track urban growth; and disaggregate demography by population density, gender, religion, and sect. They provide a spatial and quantitative background in which the largely qualitative case studies in this special issue can be situated (interactive versions of this and all other maps in this introduction can be found online at http:// lucknow.raphael-susewind.de).

FIgURE 1: Lucknow City

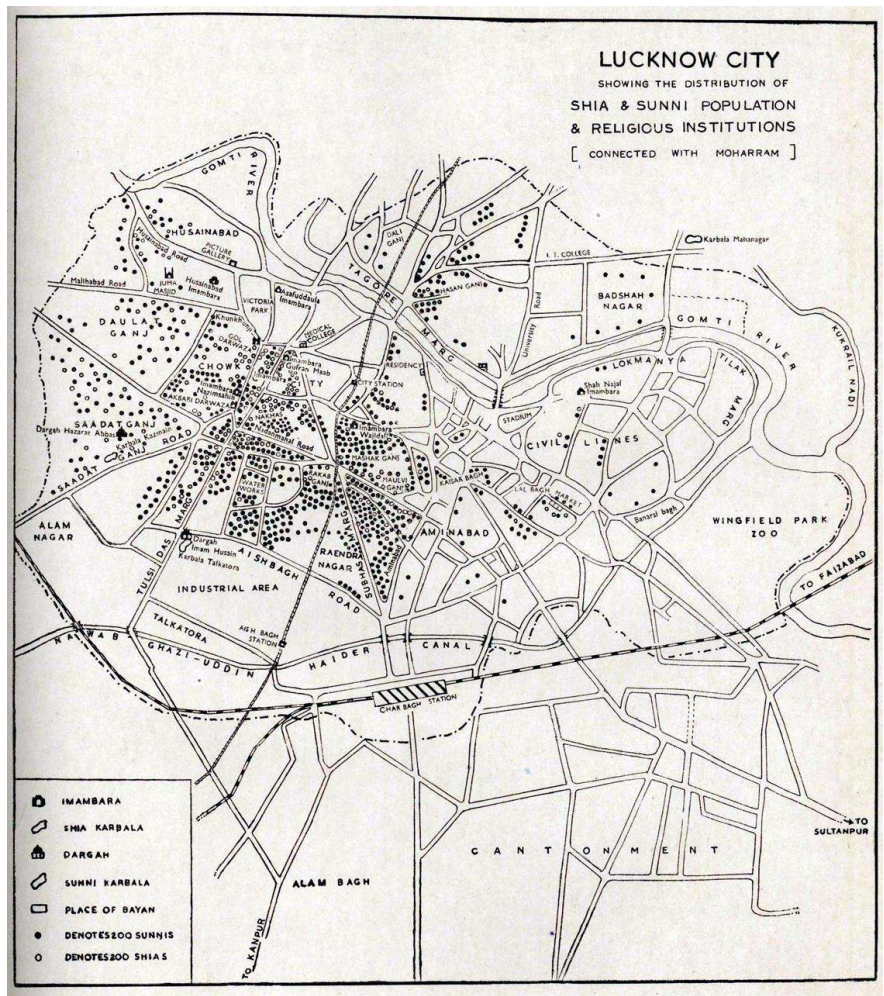

THE POPULATION OF SHIA AND SUNNI, AS WELL AS RELIgIOUS INSTITUTIONS CONNECTED WITH MUHARRAM, ARE SHOWN

CENSUS OF INDIA 1961 

the extent of the city roughly at the time of independence. Back then, the city was still centred west of the Gomti River and delimited to the south by the railway line. The old city had three distinct hubs: Chowk to the west, Aminabad to the south, and Hazratganj to the east (Mukherjee and Singh 1961; Hjortshoj 1979; Wilkinson-Weber 1999). Labyrinthine and narrow lanes (galliyan) connect members of the same ethnic, religious, and family groupings while, often, dividing them from others. The mansions (haveli) of the old city enclose wide expanses of courtyards; inside such houses, as well, men's areas (mardana) were separated from women's areas (zanana). Many families retain these gendered patterns. All three neighbourhoods of the old city of Lucknow are characterised by separations and enclosures and, in this regard, invoke for some observers the idealised 'Islamic city' (Wilkinson-Weber 1999: 2, Gilsenan 1983), although such street layouts have been found to be common to both Hindu and Muslim neighbourhoods (Abu-Lughod 1987). However, more recent, poorer urban migrants to Lucknow have reshaped life in the Aminabad Bazaar area of the old city and the slum settlements of New Lucknow, living more openly in apartments and open streets (Hjortshoj 1979: 65-66, Wilkinson-Weber 1999: 2, Taylor, this volume, Susewind, this volume). The Aminabad section of the old city (centred around the Aminabad Bazaar but inclusive of surrounding residential clusters from Qaiserbagh in the north to Charbagh in the south) grew in the 20th century with the influx of migrants; it contains the highest proportion of Hindus among the three old city neighbourhoods. Hazratganj is the newest bazaar of the old city and remains home to Lucknow's most expensive retail real estate, whereas the Chowk area is a hub of wholesaling and, as Lucknow's oldest bazaar, is dotted with the monuments of the nawabs . Further belying outmoded scholarly notions of the 'Islamic city,' in today's Lucknow, women are not simply secluded away but assert their role, as Hong Tschalär (this volume) illustrates.

But Lucknow is also a rapidly growing city and its contemporary boundaries hardly resemble those at the time of independence. Since it became capital of the British United Provinces in 1920, the city has grown from 241,000 residents to just over 3 million as of 2011 (the last master plan, from 2001, actually places the figure even higher, at 4.5 million people; Feedback Ventures 2006).

The second map (Figure 2) charts this latest phase of urban growth and shows various ways of defining the limits of the contemporary city. The city perimeter of 1961 and contemporary 'Old Lucknow,' shaded in the centre, are surrounded by four boundary lines-one indicates historical growth since the 1980s and the rest show the city limits defined administratively, based on residential density (using two indicators), and defined as a political unit. The map also shows the names and locations of some of Lucknow's more prominent neighbourhoods, including those mentioned in the various articles of this volume. 


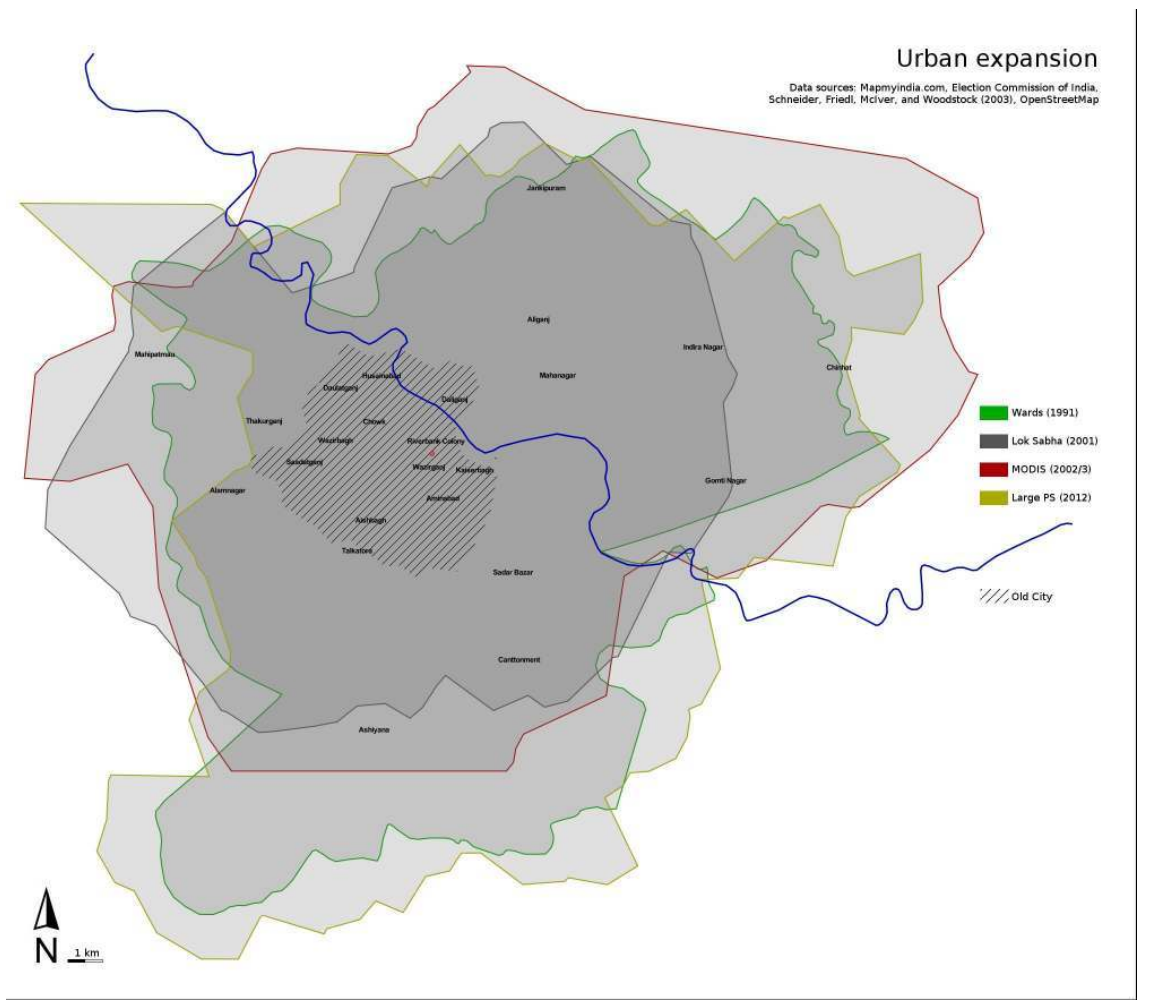

Lucknow has experienced two major waves of planned growth: in the 1940s and in the 1980s, when Lucknow's population crossed the 1 million threshold for the first time (Reeves 1997:216) and the jurisdiction of urban governance bodies was expanded (Feedback Ventures 2006: 6, cf. Majumdar 2004: 277). The neighbourhood of Mahanagar was constructed in the 1960s, Indira Nagar in the 1970s, and since the 1980s, Gomti Nagar has emerged in different stages. In the late 1990s and early 2000s, the city continued to grow mostly towards the north and east; this is suggested by the difference between the green and red boundaries in Figure 2 and is corroborated by the further analyses of satellite imagery that can be found in Taragi and Pundir (1997).

However, sometime around the 2000s, growth changed direction: currently, south Lucknow (Ashiyana and surrounding areas) appears to be the most dynamic part of the city (apart from developments within the old city, which consist of densification rather than urban expansion-see Figure 3 below and Susewind, forthcoming). This major shift in urban growth has likely been triggered by the development of Lucknow as an educational hub: a string of technical training institutes and universities, including Babasaheb Bhimrao Ambedkar University and Ram Manohar Lohia National Law University, were established in southern Lucknow around the 2000s. This led not only to an increase in construction activity in this area (reflected in the difference between the red and yellow boundaries) but also to a reinvigoration of scholarship at more traditional institutions in the old city (see Taylor, this volume). Where does the contemporary city begin and end? In a first attempt to delimit the contemporary city, the area under the jurisdiction of the Lucknow Municipal Corporation and the Lucknow Cantonment Board was mapped (as denoted in green in Figure 2). The boundaries of this area, as well as those of the administrative wards that compose it, 
change frequently, usually between local elections. The green boundary in Figure 2 is based on 1991 Census data; thus, its extent roughly reflects the limits of urban Lucknow from two decades ago, an area of $246 \mathrm{~km}^{2}$. The area under the jurisdiction of the Lucknow Municipal Corporation and the Lucknow Cantonment Board differs from that defined for state and national elections. Between the 1970s and 2008, when a major delimitation occurred, Lucknow as a parliamentary constituency was divided into five assembly segments: Lucknow East, Lucknow West, Lucknow Central, Lucknow Cantonment, and predominantly rural Mahona. After delimitation, Mahona-now called Bakshi ka Talaabwas incorporated into the rural parliamentary constituency Mohanlalganj and boundary lines within urban Lucknow were redrawn to accommodate a new assembly segment, Lucknow North. The outer limits of these latter boundaries are drawn in grey in Figure 2; they cover an area of $225 \mathrm{~km}^{2}$.

Urban growth has come to extend beyond Lucknow's administrative and political boundaries. That Lucknow is a densely populated area is reflected in boundaries derived from poly-spectral satellite images (in particular from NASA's MODIS instrument; see Friedl et al. 2003) and drawn in red in Figure 2. These data were obtained by measuring the density and character of built infrastructure vis-a-vis other kinds of land cover; based on these data, the core urban residential area could be distinguished from surrounding areas. In Lucknow, this core area amounted to $333 \mathrm{~km}^{2}$ in 2002-2003. However, these boundaries are out of date by almost a decade and more recent maps are not yet available. As a shortcut to gauge the extent of contemporary urban Lucknow, we settled on drawing a yellow boundary around areas in which polling stations featuring multiple (rather than single) polling booths predominated during the 2012 assembly elections. Larger polling stations are usually-though not exclusively-found in urban and semiurban areas; based on the areas where they are located, densely populated areas were roughly approximated. (This method yielded boundaries that were quite similar to those derived from satellite images.) Moreover, the list of polling stations as well as the number of booths provided in each station are adjusted by the Election Commission just before each election to reflect changed realities on the ground, making this the most current source of data used. This last boundary is drawn in yellow in Figure 2 and covers an area of $332 \mathrm{~km}^{2}$. 


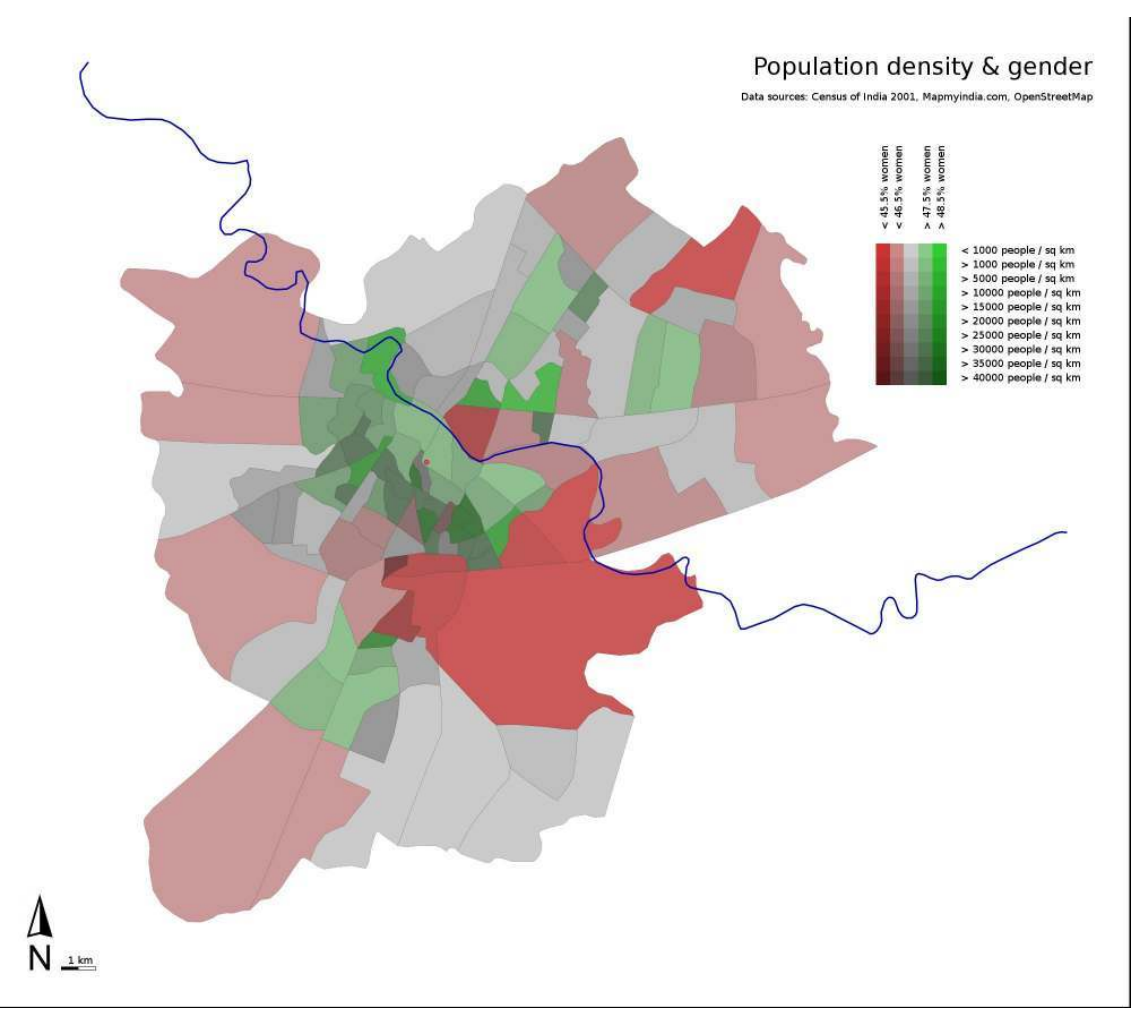

A third map (Figure 3) combines population density by ward with gender ratios (drawn from the 2001 Census). Overall, just above $48 \%$ of Lucknow's inhabitants were women according to the 2011 Census (up 1\% compared with 2001) -a slightly more equal sex ratio than the provincial average. The map shows, first, how the older parts of LucknowChowk and Aminabad-are much more densely populated than are the newer parts, as would be expected (Majumdar 2004: 29). Secondly, it reveals that men are concentrated in two areas: heavily in Lucknow Cantonment towards the southeast (a military area) and less heavily in the outskirts, where migrant labourers (unmarried or separated from their wives) tend to settle. In the outskirts, one area is an exception to this concentration of men: a cluster of wards towards the south-eastern outskirts where Lucknow's new education hub is located, which attracts migration that is more gender-balanced (Feedback Ventures 2006: 7). In addition to urban growth, population density, and the gender balance, religious demographics are of particular interest to the papers in this volume. Unfortunately, the official data on religion remain notoriously inaccessible at the local level. Census data, for instance, is only disaggregated to the Tehsil level; since all of urban Lucknow falls within one Tehsil, this is of little use. Yet recent advances in big data analytics combined with e-governance initiatives make it possible to develop alternatives, since they enable lists of names, such as electoral rolls at the booth level, property records at the street level, and BPL lists at the ward level, to be used as novel data sources: like anywhere else, Indian names allow educated guesses regarding the religion of the person who bears the name.

A fourth map (Figure 4) visualises the spatial distribution of Muslims across Lucknow on the basis of names on the electoral rolls of Uttar Pradesh; a linguistic computer algorithm that accomplishes such guesses with very high aggregate accuracy was used (Susewind, in press, 2013). The electoral rolls are a natural choice for approximating populations at 
large: extensive in coverage, published at a low spatial resolution, updated on a yearly basis, and closely watched by competing political parties, they are arguably the most accurate data source available. While they exclude children and those who have opted not to register to vote, there is little reason to believe that the data differ between Muslims and non-Muslims.

FIgURE 4: Muslim electors, Hajj pilgrims, and institutions

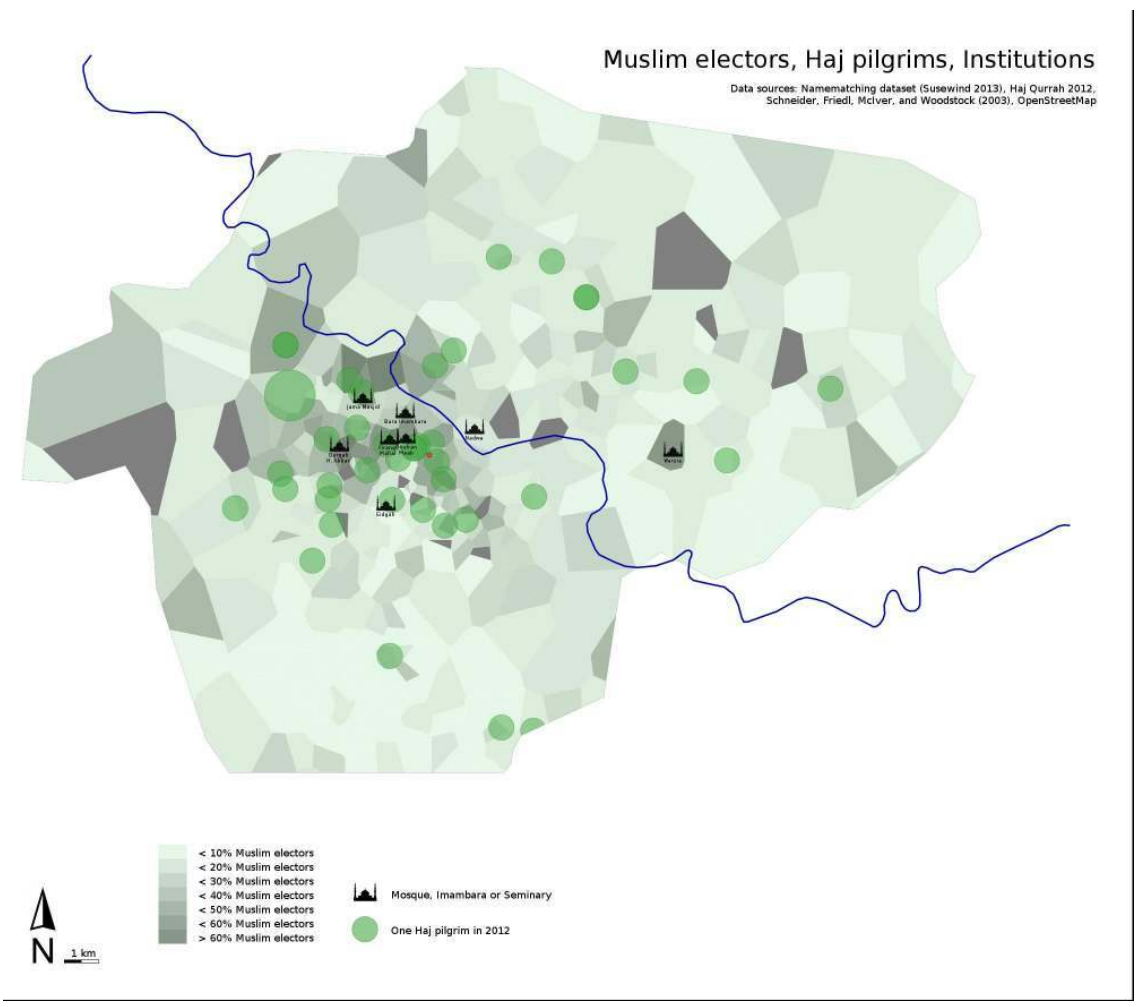

The map demonstrates that most Muslims still tend to live in the old city rather than across the river in New Lucknow. Exceptions from this general pattern are the Daliganj area (often considered part of the old city), two polling stations just east of the Nadwa Seminary (see Taylor, this volume), and fairly isolated blips scattered across Indira Nagar and Gomti Nagar (some of which are former Muslim villages now surrounded by new colonies, such as Ujariyaon, a village famous for its syncretic culture and home to the Barelvi-inspired Warzia Madaris). The map also suggests that residential neighbourhoods are more segregated in New Lucknow than in the old city, corroborating the key imaginary of the old city as a 'composite culture': the map shows that similar numbers of Muslims live in Muslim-minority, mixed, and Muslim-majority neighbourhoods in the old city, whereas Muslims across the river in New Lucknow are much more likely to live in Muslim-minority areas.

Beyond approximated population shares, deliberately included in the map are two other indicators of Muslim life: the tentative distribution of Hajj pilgrims (drawn from the 2012 qurrah), an indicator of religious practice by and large coextensive with the Muslim population at large, and the locations of major Islamic institutions. Most of these are found in the Chowk, including all of the major Shi'a institutions: the Jama Masjid and Bara Imambara, signs of former Nawabi authority; Imambara Ghufran Maab, the seat of Lucknow's most powerful Shi'a clerical dynasty, headed by Maulanas Kalbe Jawwad and 
Kalbe Sadiq (Jones 2012); and Dargah Hazrat Abbas, the seat of their main competitor, Maulana Yasoob Abbas. In terms of Sunni institutions, the Nadwa Seminary just across the river clearly dominates the scene (Malik 1997; Taylor, this volume), seconded by the old and now defunct Firangi Mahal in Chowk (Robinson 2001) as well as the 'new' Firangi Mahal, headed by Maulana Khalid Rashid and located at the main Eidgah towards Talkatora (the large open area were Eid prayers are held, which was customarily located outside erstwhile city boundaries). Finally, there is a Barelvi centre frequented by both Sunni and Shi'a in the old village of Ujariyaon, a place marginalised not only in spatial terms.

This multi-perspectival representation is meant to preserve the notion of community multidimensionality and urban heterogeneity: does one's being Muslim inhere in one's name (and, by extension, lineage)? Or does it depend on the observance of key Islamic commandments (such as giving alms or taking the pilgrimage to Mecca)? Alternatively, is Muslimness nested within certain Islamic institutions, madrasas, and the clergy in particular?

Given that Shi'a-Sunni relations are of particular interest in Lucknow, and given that sectarian data are scarcer than are communal data, it is tempting to apply a similar methodology to identify Shi'a and Sunni names and map their approximate share of the population. However, since names in these groups are not empirically distinct, this would result in far less accurate estimates.

FIgURE 5: Shia electors and Muharram processions

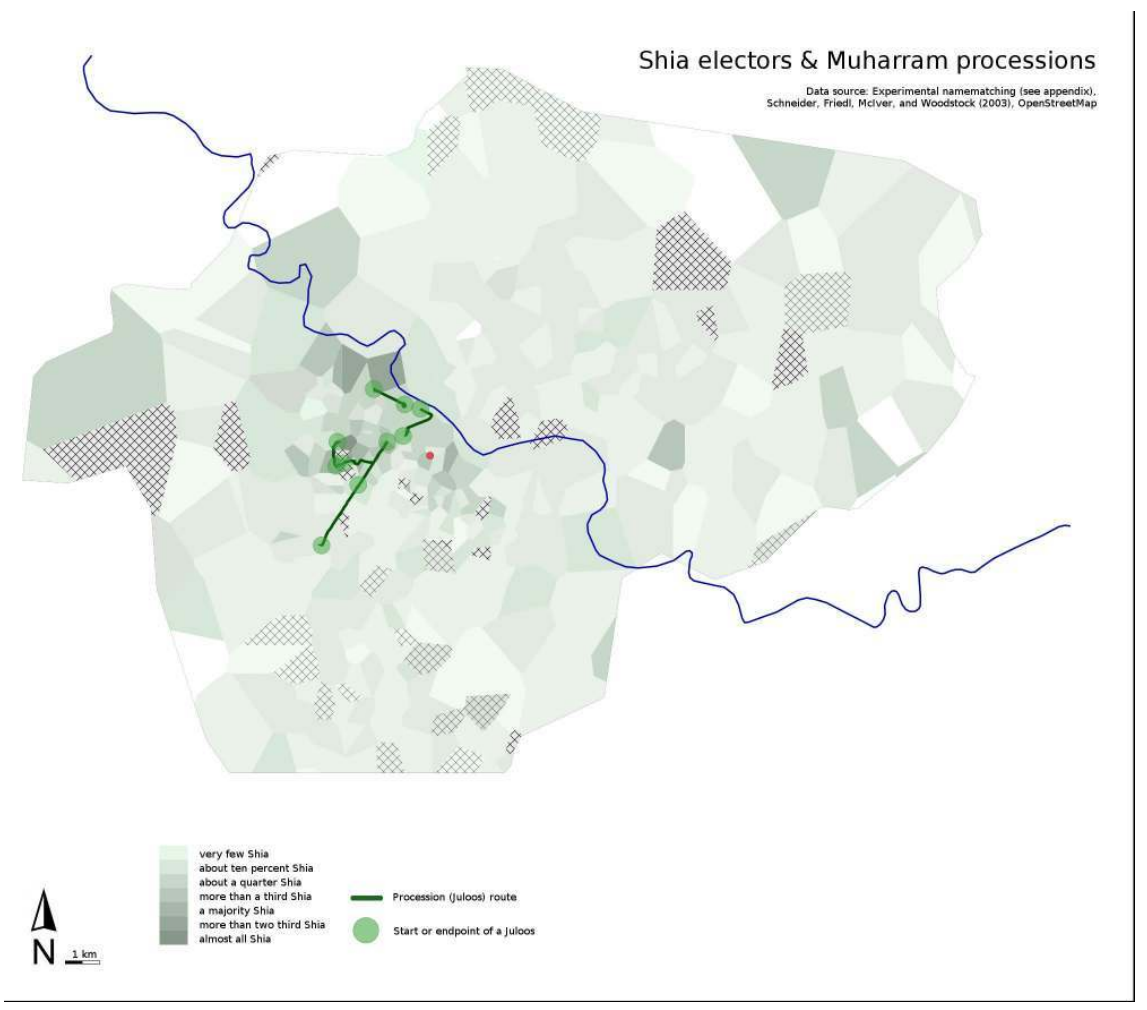

39 With a number of caveats, a final map (Figure 5) identifies Shi'a strongholds with sufficient reliability, although the map does not reflect how strong these strongholds are. Two major areas of Shi'a concentration are noticeable: Hussainabad (the former royal quarters) and Kashmiri Mohalla (frequently described as a 'Shi'a ghetto' by Lucknowites; 
Verniers 2012; Yadav 2012). Overall, Lucknow's Shi'a account for a quarter to a third of the city's Muslim population today, consistent with estimates reported by Verniers (2012) and Graff et al. (1997), but significantly higher than the $10 \%$ reported in the last sectarian Census in 1901 (Hasan 1997: 127) and the limited number of Shi'a households indicated in the first map (Figure 1). The Shi'a-Sunni map is inclusive of more than one way of mapping the sectarian landscape of Lucknow. An important part of Shi'a ritual life is the commemoration of the Karbala tragedy, which, in spatial terms, is observed in highly significant ways (Nejad 2013). Lucknow's Shi'a take great pride in extending their Azadari activities for two months and eight days; they undertake processions, or juloos, across the city (in particular between the first of Muharram and Ashura). Due to violent sectarian clashes throughout the last century, these processions were banned for two decades; now, only nine specific processions are allowed by the district administration.

The spatial layout of contemporary Muharram routes depicted in Figure 5 bears testimony to this sustained sectarian tension: many smaller processions in mixed neighbourhoods remain banned or are limited to semi-public spaces; the ones allowed are restricted to areas easy to police. The Shahi and Mehndi Juloos at the beginning of Muharram run from Bara to Chota Imambara in Chowk and the Juloos on Eighth Muharram proceeds from Dariya Wali Masjid to Imambara Ghufran Maab. Neither substantially pass through residential areas. Most of the other processions, however, either follow Victoria Street, a wide main road usually cordoned off by riot police, or pass through Shi'a dominated areas (with the partial exception of southern Nakhas). Interestingly, two of the juloos permitted by the district magistrate take place outside of Muharram-during Ramadan-and have, theologically speaking, much less of a sectarian nature (as they commemorate the attack on Imam Ali much prior to the sectarian split). However, they are counted as Shi'a events, are undertaken by Shi'as, and run through predominantly Shi'a areas.

\section{Overview of This Special Issue}

41 Against the backdrop of the themes and discourses mentioned in this introduction and the spatial layout just outlined, this special issue aims to bring disciplinary diversity to an object overwhelmingly represented in historical accounts and seeks to add fresh empirical and theoretical insights from Lucknow to recent debates on South Asian citiesdebates in which the city of nawabs seems so conspicuously absent. The first section of papers directly addresses the appropriations and popular revisions of Lucknow's history. Both Jones and Lee revisit and question 'cosmopolitan,' elite culture of the city made famous in history and literature. Justin Jones illustrates how colonial-era representations of Lucknow constructed imaginaries of the city's past, inverting the conventional Habermasian model of the public sphere as replete with the symbols of modernity and reform. Lucknow's old 'fashions'-particularly the traditions of tehzib-are better understood as politically motivated symbols of the remembered city intended to model contemporary Indian cosmopolitanism. Joel Lee continues the re-examination of Lucknow's purported cosmopolitanism with rich ethnography of Dalits from the Balmiki, Lal Begi, Dhanuk, and Jallad groups. Despite the increasing communalism of the 20th century, which has been said to have fractured Indian society along religious lines, Lee's account of the city's sanitation workers reveals that Hindu and Muslim rituals and 
identities have become blurred and that concomitant bureaucratic struggles (such as that of Jagdish, son of Ahmad) have taken place.

The contributions of Susewind and Hong Tschalär turn to contemporary developments and explore the politics of intra-Muslim diversity in the context of examples of class, gender, and Shi'a-Sunni relations. By breaking with the idea of a uniform Muslim 'community' in the present, they implicitly also question its existence in the past. Susewind takes us to the neighbourhood of Wazirganj, the site of a highly publicised murder and Shi'a-Sunni skirmishes that lacerated the city's societal fabric. He complicates the conventional sociological explanations of interreligious violence, instead emplacing it as the product of vernacularised democracy, transformed local economies, and ideologies of upward social mobility propounded by Shi'i Muslim preachers. Mengia Hong Tschalär in turn presents the city's Muslim women's rights activists as they challenge patriarchal ideas within their communities and carve out space for themselves in the public sphere. The new visibility of Muslim women activists is starkly noticeable in their gatherings in parks, a newly built women's mosque, bodily intrusions into men-only congregational prayer, and legal assertions. Christopher Taylor's contribution illustrates how Lucknow's Muslim 'ulama keeps the city's traditions of Islamic learning alive through fundraising from its urban and transnational donor base. Describing madrasa students' career aspirations, Taylor analyses their perceptions of Islamic learning. For these students, Islamic learning is not an outdated mode of education but, rather imparts cultural capital and skills translatable to India's modern urban economy: the past and the present combined. In a postscript, Sandria Freitag, a historian among anthropologists (cf. Cohn 1987), reflects on the value of interdisciplinarity and reviews how the studies on Lucknow assembled here contribute to the growing scholarly corpus on the cultural history of Indian cities.

\section{BIBLIOGRAPHY}

Abu-Lughod, Janet (1987) 'The Islamic City-Historic Myth, Islamic Essence, and Contemporary Relevance', International Journal of Middle East Studies, 19(2), pp. 155-76.

Alavi, Seema (2008) Islam and Healing: Loss and Recovery of an Indo-Muslim Medical Tradition, 16001900, Basingstoke: Palgrave Macmillan.

Appadurai, Arjun (1995) 'The Production of Locality', in Richard Fardon (ed.), Counterworks: Managing the diversity of knowledge, Abingdon: Routledge, pp. 204-25.

Ballhatchet, Kenneth; Harrison, John (1980) The City in South Asia: Pre-Modern and Modern, Delhi: Routledge.

Bard, Amy (2002) Desolate Victory: Shi ' $i$ Women and the Marsiyah Texts of Lucknow, PhD Dissertation submitted to Columbia University.

Barth, Frederik (1969) Ethnic Groups and Boundaries, Oslo: Universitetsforlaget. 
Basant, Rakesh; Shariff, Abusaleh. (eds.) (2010) Handbook of Muslims in India: Empirical and Policy Perspectives, Oxford: Oxford University Press.

Bayly, Christopher (1975) The Local Roots of Indian Politics: Allahabad, 1880-1920, Oxford: Clarendon Press.

Bhadra, Gautam (1985) 'Four Rebels of Eighteen Fifty Seven', in Ranajit Guha (ed.), Subaltern Studies IV, New Delhi: Oxford University Press, pp. 229-75.

Bose, N. K. (1968) Calcutta 1964: A Social Survey, Bombay: Lalvani Publishers.

Brosius, Christiane (2013) India's Middle Class: New Forms of Urban Leisure, Consumption and Prosperity , New York: Routledge.

Burke, Peter (1997) Varieties of Cultural History, Ithaca: Cornell University Press.

Census of India (1961) Moharram in Two Cities (Lucknow and Delhi). Census monograph series, part VII-B: Fairs and festivals, New Delhi: Ministry of Home Affairs, Government of India.

Chandavarkar, Raj (2009) History, Culture and the Indian City, Cambridge: Cambridge University Press.

Chakrabarti, Indranil (2006) 'Local Governance: Politics and Neighbourhood Activism in Calcutta', in Geert de Neve \& Henrike Donner (eds.), The Meaning of the Local: Politics of Place in Urban India, London: Routledge, pp. 89-115.

Chakravarty, Gautam (2005) The Indian Mutiny and the British Imagination, Cambridge: Cambridge University Press.

Chaudhuri, S. B. (1965) Civil Rebellion and Theories of the Indian Mutiny, Calcutta: World Press.

Cohn, Bernard (1987) An Anthropologist Among the Historians and Other Essays, Delhi: Oxford University Press.

Cole, Juan Ricardo (1988) Roots of North Indian Shi'ism in Iran and Iraq: Religion and State in Awadh, 1722-1859, Berkeley: University of California Press.

Datta, Kalikinkar (1967) Reflections on the Mutiny, Calcutta: Calcutta University Press.

Dickey, Sara (2013) ‘Apprehensions: On gaining Recognition as Middle Class in Madurai', Contributions to Indian Sociology, 47(2), pp. 217-43.

Dobbin, Christine (1972) Urban Leadership in Western India: Politics and Communities in Bombay City, 1840-1885, London: Oxford University Press.

Donner, Henrike (2006) 'The Politics of Gender, Class, and Community in a Central Calcutta Neighbourhood', in Geert de Neve \& Henrike Donner (eds.), The Meaning of the Local: Politics of Place in Urban India, London: Routledge, pp. 141-59.

Donner, Henrike; de Neve, Geert (2006) 'Space, Place and Globalisation: Revisiting the Urban Neighbourhood in India', in Geert de Neve \& Henrike Donner (eds.), The Meaning of the Local: Politics of Place in Urban India, London: Routledge, pp. 1-20.

Dumont, Louis (1980) Homo Hierarchicus, Chicago: University of Chicago Press.

Feedback Ventures (2006) City Development Plan Lucknow. Submitted to Government of Uttar Pradesh, August 14.

Ferguson, James; Gupta, Akhil (2002) 'Spatializing States: Toward an Ethnography of Neoliberal Governmentality’, American Ethnologist, 29(4), pp. 981-1002. 
Fernandes, Leela (2006) India's New Middle Class: Democratic Politics in an Era of Economic Reform, Minneapolis: University Of Minnesota Press.

Freitag, Sandria (1989), Collective Action and Community: Public Arenas and the Emergence of Communalism in North India, Delhi: Oxford University Press.

Freitag, Sandria (2014) 'A Visual History of Three Lucknows', South Asia: Journal of South Asian Studies, 37(3), pp. 431-53.

Friedl, Mark A.; McIver, Douglas K.; Schneider, Annemarie; Woodcock, Curtis E. (2003) 'Mapping Urban Areas by Fusing Multiple Sources of Coarse Resolution Remotely Sensed Data', Photogrammetric Engineering and Remote Sensing, 69, pp. 1377-86.

Froystad, Katinka (2006) Anonymous Encounters: Class Categorisation and Social Distancing in Public Places, in Geert de Neve \& Henrike Donner (eds.), The Meaning of the Local: Politics of Place in Urban India, London: Routledge, pp. 159-81.

Frykenberg, R. (1986) Delhi Through the Ages: Essays in Urban History, Culture, and Society, New York: Oxford University Press.

Gandhi, Mahatma (1966) The Collected Works of Mahatma Gandhi, New Delhi: Ministry of information and broadcasting, Government of India.

Gandhi, Ajay; Hoek, Lotte (2012), 'Introduction to Crowds and Conviviality: Ethnographies of the South Asian City’, Ethnography, 13(1), pp. 3-11.

Gayer, Laurent; Jaffrelot, Christophe (eds.) (2012) Muslims in Indian Cities: Trajectories of Marginalisation, London: Hurst.

Geertz, Clifford (1973) The Interpretation of Cultures, New York: Basic Books.

Ghassem-Fachandi, Parvis (2012) 'The City Threshold: Mushroom Temples and Magic Remains in Ahmedabad', Ethnography, 13(1), pp. 12-27.

Gilsenan, Michael (1983) Recognizing Islam: Religion and Society in the Modern Middle East, New York: Pantheon Books.

Gooptu, Nandini (2001) The Politics of the Urban Poor in Early Twentieth-Century India, Cambridge: Cambridge University Press.

Gooptu, Nandini (ed.) (2013) Enterprise Culture in Neoliberal India: Studies in Youth, Class, Work and Media, New York: Routledge.

Graff, Violette; Gupta, Narayani; Hasan, Mushirul (1997) 'Introduction', in Violette Graff (ed.), Lucknow: Memories of a City, New Delhi: Oxford University Press, pp. 1-15.

Guha, Ranajit (1983) ‘The Prose of Counter-Insurgency', in Nicholas Dirks, Geoff Eley \& Sherry B. Ortner (eds.), Culture/Power/History: A Reader in Contemporary Social Theory, Princeton: Princeton University Press, pp. 336-71.

Gupta, Akhil (2012) Red Tape: Bureaucracy, Structural Violence, and Poverty in India, Durham: Duke University Press.

Habermas, Jürgen (1991) The Structural Transformations of the Public Sphere: An Inquiry into a Category of Bourgeois Society (Thomas Burger, Trans.), Cambridge: MIT Press.

Hasan, Mushirul (1997) 'Traditional Rites and Contested Meanings: Sectarian Strife in Colonial Lucknow', in Violette. Graff (ed.), Lucknow: Memories of a City, New Delhi: Oxford University Press, pp. 114-35. 
Haynes, Douglas (1991) Rhetoric and Ritual in Colonial India: The Shaping of a Public Culture in Surat City, 1852-1928, Berkeley: University of California Press.

Haynes, Douglas; Rao, Nikhil (2013). 'Beyond the Colonial City: Re-Evaluating the Urban History of India, ca. 1920-1970', South Asia: Journal of South Asian Studies, 13(3), pp. 317-35.

Hjortshoj, Keith (1979) Urban Structures and Transformations in Lucknow, India, Ithaca: Program on International Studies in Planning in conjunction with the Program in Urban and Regional Studies, Cornell University.

Hodgson, Marshall (1974) The Venture of Islam: Conscience and History in a World Civilization, Vol I, Chicago: University of Chicago Press.

Hunt, Lynn (1989) The New Cultural History: Papers from the Conference Entitled 'French History: Texts and Culture'. Berkeley: University of California Press.

Jaffrelot, Christophe (2003) India's Silent Revolution: The Rise of the Lower Castes in North India, London: Hurst.

Jeffrey, Craig; Jeffery, Patricia; Jeffery, Roger (2008) Degrees Without Freedom?: Education, Masculinities, and Unemployment in North India, Palo Alto: Stanford University Press.

Jones, Justin (2012) Shi'a Islam in Colonial India: Religion, Community and Sectarianism, Cambridge: Cambridge University Press.

Joshi, Sanjay (2001) Fractured Modernity: Making of a Middle Class in Colonial North India, New Delhi: Oxford University Press.

Keshani, Hussein (2003) The Architecture of Ritual: Eighteenth-Century Lucknow and the Making of the Great Imambarah Complex, a Forgotten World Monument, PhD Dissertation submitted to University of Victoria.

Khilnani, Sunil (1997) The Idea of India, London: Hamish Hamilton.

King, Anthony (1976) Colonial Urban Development : Culture, Social Power and Environment, London: Routledge.

Lahiri, Shompa (2012) 'Remembering the City: Translocality and the Senses', Social \& Cultural Geography, 12(8), pp. 855-69.

Liechty, Mark (2003) Suitably Modern: Making Middle-Class Culture in a New Consumer Society, Princeton: Princeton University Press.

Llewellyn-Jones, Rosie (1985) A Fatal Friendship: The Nawabs, the British, and the City of Lucknow, Oxford: Oxford University Press.

Llewellyn-Jones, Rosie (1980) ‘The City of Lucknow Before 1856', in Ballhatchet, Kenneth; Harrison, John (eds), The City in South Asia: Pre-Modern and Modern, London: Curzon, pp. 91-98.

Lynch, Owen (1969) The Politics of Untouchability: Social Mobility and Social Change in a City of India, New York: Columbia University Press.

Malik, Jamil (1997) Islamische Gelehrtenkultur in Nordindien, Leiden: Brill.

Majumdar, Ramesh Chandra (1957) The Sepoy Mutiny and the Revolt of 1857, Calcutta: K. L. Mukhopadhyay.

Majumdar, Paramita (2004) Dynamics of Urban Development: The Changing Face of Lucknow, Delhi: Abhijeet. 
Markel, Stephen (2010) India's Fabled City: The Art of Courtly Lucknow, Los Angeles: County Museum of Art.

Marx, Karl; Engels, Friedrich. (1975). The First Indian War of Independence, 1857-1859, Moscow: Progress.

Metcalf, Barbara Daly (1982) Islamic Revival in British India: Deoband, 1860-1900, Oxford: Oxford University Press.

Mines, Mattison (2006) 'Temples and Charity: The Neighbourhood Styles of the Komati and Beeri Chettiar Merchants of Madras City', in Geert de Neve \& Henrike Donner (eds.), The Meaning of the Local: Politics of Place in Urban India, London: Routledge, pp. 89-115.

Misra, Ranganath; Mahmood, Tahir; Wilson, Anil; Singh, Mohinder; Das, Asha. (2007) Report of the National Commission for Religious and Linguistic Minorities, New Delhi: Ministry of Minority Affairs, Government of India.

Mitchell, Lisa (2014) 'The Visual Turn in Political Anthropology and the Mediation of Political Practice in Contemporary India', South Asia: Journal of South Asian Studies, 37(3), pp. 515-40.

Mukerjee, Radhakamal; Singh, Baljit. (1961) Social Profiles of a Metropolis: Social and Economic Structure of Lucknow, Capital of Uttar Pradesh, 1954-56, London: Asia Publishing House.

Naim, C. M. (1983) 'The Art of the Urdu Marsiya', in Milton Israel \& N. K. Wagle (eds.), Islamic Society and Culture: Essays in Honour of Professor Aziz Ahmad, Delhi: Manohar, pp. 101-16.

Naim, C. M.; Petievich, Carla (1997) 'Urdu in Lucknow / Lucknow in Urdu', in Violette Graff (ed.), Lucknow: Memories of a City, New Delhi: Oxford University Press, pp. 165-80.

Nandy, Ashis (2002) Time Warps: Silent and Evasive Pasts in Indian Politics and Religion, New Brunswick, NJ: Rutgers University Press.

Nandy, Ashis (2006) An Ambiguous Journey to the City: The Village and Other Odd Ruins of the Self in the Indian Imagination, Oxford: Oxford University Press.

Nejad, Reza Majoudi (2013) 'The Discursive Manifestation of Past and Present Through the Spatial Organization of the Ashura Procession', Space and Culture,16(2), pp. 133-60.

Neveling, Patrick (2014) 'Structural Contingencies and Untimely Coincidences in the Making of Neoliberal India: The Kandla Free Trade Zone, 1965-91', Contributions to Indian Sociology, 48(1), pp. 17-43.

Omvedt, Gail (1994) Dalits and the Democratic Revolution: Dr Ambedkar and the Dalit Movement in Colonial India, New Delhi: Sage.

Petievich, Carla (1992) Assembly of Rivals: Delhi, Lucknow and the Urdu Ghazal, Delhi: Manohar. Prakash, Gyan (2002) ‘The Urban Turn', in Ravi Vasudevan, Ravi Sundaram, Jeebesh Bagchi, Monica Narula, Geert Lovink, \& Shuddhabrata Sengupta (eds.), Sarai Reader 02: The Cities of Everyday Life, Delhi: Rainbow Publishers, pp. 2-7.

Ramachandran, R. (1989) Urbanization and Urban Systems in India, Delhi: Oxford University Press.

Rao, M. S. A. (1986) Studies in Migration, Delhi: Manohar.

Reeves, Peter (1997) 'Lucknow Politics: 1920-47', in Violette Graff (ed.), Lucknow: Memories of a City , New Delhi: Oxford University Press, pp. 213-26.

Robinson, Francis (1977) [Review of the book Lucknow: The Last Phase of an Oriental Culture, by Abdul Halim Sharar; E. S. Harcourt; Fakhir Hussain], Modern Asian Studies, 11(2), pp. 298-302. 
Robinson, Francis (2001) The 'Ulama of Faranghi Mahall and Islamic Culture in South Asia, London: Hurst.

Sachar, Rajinder; Hamid, Sayid; Ooman, T. K; Basith, M. A; Majeed, Akthar; Shariff, Abusaleh; Basant, Rakesh. (2006) Report on Social, Economic and Educational Status of the Muslim Community of India, New Delhi: Prime Minister's High Level Committee, Cabinet Secretariat, Government of India.

Sen, Surendra Nath (1977) Eighteen Fifty Seven, New Delhi: Publications Division, Ministry of Information \& Broadcasting, Government of India.

Sharar, 'Abdul HaTim (2001) Lucknow: The Last Phase of an Oriental Culture, in E. S. Harcourt \& Hussain, Fakhir (eds.), New Delhi: Oxford University Press.

Sharma, R. N; Sita, K. (ed.) (2001) Issues in Urban Development: A Case of Navi, Mumbai, Jaipur and New Delhi, New Delhi: Sage.

Shatkin, Gavin (2013) Contesting the Indian city: Global Visions and the Politics of the Local, International Journal of Urban and Regional Research, 38(1), pp. 1-13.

Siddique, M. K. A. (1982) Aspects of Society and Culture in Calcutta, Calcutta: Anthropological Survey of India.

Singer, Milton B.; Cohen, Bernard S. (1968) Structure and Change in Indian Society, Chicago: Aldine.

Subrahmanyam, Sanjay (1990) The Political Economy of Commerce: Southern India, 1500-1650, Cambridge: Cambridge University Press.

Susewind, Raphael (2013) Data on religion and politics in Uttar Pradesh. Published under an ODbL 1.0 license. Retrieved from http://data.raphael-susewind.de

Susewind, Raphael (in press) 'What's in a Name? Probabilistic Inference of Religious Community from South Asian Names', Field Methods, 27(3).

Susewind, Raphael (forthcoming) 'Spatial Segregation, Real Estate Markets and the Political Economy of Corruption in an Indian city', Journal of South Asian Development, 10(3).

Talwar-Oldenburg, Veena (1984) The Making of Colonial Lucknow, Princeton: Princeton University Press.

Taragi, R. C. S.; Pundir, P. P. S. (1997) 'Use of Satellite Data in Urban Sprawl and Land Use Studies: A Case of Lucknow City', Photonirvachak, 25(2), pp. 113-18.

Trivedi, Madhu (2010) The Making of the Awadh Culture, New Delhi: Primus Books.

Turner, Victor (1969) The Ritual Process: Structure and Anti-Structure, Chicago: Aldine.

Verniers, Gilles (2012) 'A Minority Within a Minority: The Shias of Kashmiri Mohalla, Lucknow’, in Laurent Gayer \& Christophe Jaffrelot (eds.), Muslims in Indian Cities: Trajectories of Marginalisation , London: Hurst, pp. 105-28.

White, Hayden (2014) Metahistory: The Historical Imagination in Nineteenth-Century Europe, Baltimore: Johns Hopkins University Press [1973].

Wilkinson-Weber, Claire (1999) Embroidering Lives: Women's Work and Skill in the Lucknow Embroidery Industry, Albany: State University of New York Press.

Yadav, Sarvendra (2012) Social Mobility among the Shias: An Intergenerational Study of Muslims of Lucknow, Saarbrücken: LAP Lambert. 
Zaman, Muhammad Qasim (2003) The Ulama in Contemporary Islam: Custodians of Change, Princeton: Princeton University Press.

\section{ABSTRACTS}

Lucknow, a city once dominated by Shi'a nawab rulers, is now known for elites' nostalgia for Islamicate pasts and masses seeking better futures. This special issue builds interdisciplinary dialogue about a city overwhelmingly represented in historical accounts and emplaces Lucknow within recent investigation of urban India in which the city of nawabs is largely absent. Focusing on the old city of Lucknow where Muslims still demographically predominate, our introduction blends ethnographic exploration of cultural memory with new statistical data on the old city's changing population, socioeconomic 'backwardness,' and segregation. We frame Lucknow's Islamicate old city in contemporary times as a place where north India's beleaguered Muslim minority negotiates between their remembered cosmopolitan past and a present burdened by structural violence and communal riots-blending (rather than choosing between) modernity and tradition, cosmopolitanism and provinciality, melancholia and aspirations, history and future.

INDEX

Keywords: urban studies, Indian Muslims, Lucknow, demography, historiography, history

\section{AUTHORS}

\section{RAPHAEL SUSEWIND}

Associate of the Contemporary South Asia Studies Program, University of Oxford

\section{CHRISTOPHER B. TAYLOR}

Visiting Researcher, Berkley Center for Religion, Peace, and World Affairs, Georgetown

University 